\title{
Characterizing Diesel Particulate Filter Failure During Commercial Fleet Use due to Pinholes, Melting, Cracking, and Fouling
}

\author{
Kun Yang $^{1}$ • John T. Fox ${ }^{1} \cdot$ Robert Hunsicker $^{2}$
}

Received: 17 August 2015 / Revised: 26 February 2016 / Accepted: 2 March 2016 / Published online: 8 April 2016

(C) Springer International Publishing Switzerland 2016

\begin{abstract}
Diesel particulate filters (DPFs) are essential particulate matter emission control devices. Some diesel particulate filters have been observed to fail during industrial-fleet vehicle use. DPFs that fail during vehicle use compromise particulate matter emission capture. Herein, failures in cordierite DPF substrates observed during commercial fleet use were characterized as pinhole failure, melt failure, crack failure, and fouling failure. The observed failures were correlated to particulate matter chemical composition and physical changes in the cordierite substrate of the exhausted DPFs. The physical-chemical characteristics of pinhole failure, melt failure, crack failure, and fouling failure were determined by applying scanning electron microscopy-energy dispersive spectrometry (SEM-EDS), X-ray photoelectron spectroscopy (XPS), and X-ray diffraction (XRD). Results indicate that the chemical composition and crystalline structures of cordierite DPF substrate changed according to the failure characterization. The specific changes to the cordierite substrate during failure can contribute towards understanding fundamental DPF failure mechanisms.
\end{abstract}

Keywords Diesel particulate filter · DPF ash - EGR fouling · Pinholes $\cdot$ Cracks $\cdot$ Melting

John T. Fox

Jtf211@lehigh.edu

Lehigh University, 1 W. Packer Avenue, Bethlehem, PA 18015, USA

2 Hunsicker Emissions Services LLC, P.O. Box 44, Earlington, PA 18918, USA

\section{Introduction}

Diesel engines power railcars, trucks, and ships-which account for $85 \%$ of the US ton miles of freight [1]. In 2013, mobile sources, including highway and non-road vehicles combined to be the second leading anthropogenic source of particulate matter (both $\mathrm{PM}_{2.5}$ and $\mathrm{PM}_{10}$ ) in the USA [2]. Diesel engine particulate matter (PM) is formed from combustion of fuel and lubricating oil and results in ash and soot. Incomplete combustion of petrochemicals results in soot, which is the insoluble organic carbon component of particulate matter, and consists of agglomerates of various sizes ranging from 0.5 to $5 \mu \mathrm{m}$ [3]. Additionally, there is an ash component of the particulate matter, which is the inorganic noncombustible fraction. Aggregates of ash are reportedly 45$160 \mathrm{~nm}$ in size [3]. The particulate matter (PM) emitted by heavy diesel vehicles can be captured in the diesel particulate filter (DPF), a required emission control device to meet particulate matter emission standards of $0.01 \mathrm{~g} / \mathrm{bhp}-\mathrm{h}$ [4].

DPFs are available in multiple configurations; however, wall-flow DPFs are the most common. Wall-flow devices remove PM by forcing exhaust through porous walls separating adjacent channels in a monolithic substrate [5, 6]. DPFs are typically manufactured from cordierite, silicon carbide, aluminum titanate, and mullite [7]. The more commonly used cordierite is a synthetic ceramic which possesses a chemical composition of $2 \mathrm{MgO}-2 \mathrm{Al}_{2} \mathrm{O}_{3}-5 \mathrm{SiO}_{2}$ [8]. DPF substrates made with each of these materials are characterized by very good filtration efficiency, with PM capture efficiency greater than $90 \%[5,6]$. However, the accumulation of soot and ash in the filter induces back pressure on the diesel engine, which can cause diesel vehicles to consume more fuel, lower power output, effect engine durability, and under worse case scenarios render the engine/vehicle un-operable [9-13]. For this reason, engine manufacturers recommend temporarily removing the 
DPF at prescribed maintenance intervals, to clean out the accumulated ash and relieve engine back pressure.

In order to minimize back pressure on the diesel engine during vehicle operation, periodic on-board regeneration of the DPF occurs via burning off accumulated soot. The incombustible ash remains following DPF regeneration and accumulates in the substrate channels and walls $[13,14]$. During uncontrolled on-board regeneration temperatures, DPF substrates may suffer thermal damage due to excessive temperature peaks, above $1200{ }^{\circ} \mathrm{C}$, which occur due to exothermic combustion of soot and the limited heat capacity of the exhaust gas and DPF substrate material [7, 8, 15-17]. Pinholes, melts, and cracks have been found within cordierite and silicon carbide substrate materials after exposure to uncontrolled regeneration conditions [15, 16]. While previous laboratory controlled studies have confirmed the corrosive impact ash imparts on DPFs, the underlying mechanisms responsible for DPF failure and the interaction between ash/substrate is not well understood. DPF failure due to ash/substrate interaction has been successfully modeled using catastrophe theory and diffeomorphism transformation considering flow resistance due to ash deposition, yet this model does not identify the specific underlying mechanisms causing failure [18]. Several hypotheses exist to explain DPF substrate failure, where interaction between substrate materials and alkali compounds significantly reduced the melting point of the cordierite and silicon carbide, with average melt temperatures lowered to about $700-900{ }^{\circ} \mathrm{C}[7,8,15,17]$. This temperature range is within the maximum peak temperatures experienced by the filter under controlled regeneration conditions.

With respect to specific compounds, sodium-rich ash was shown as corrosively damaging to both cordierite and silicon carbide materials [7, 17]. Interaction between substrate materials and alkali compounds in the presence of additional ash materials, including $\mathrm{Ca}, \mathrm{Mg}$, and $\mathrm{Zn}$ in phosphate-sulfateoxide forms, was observed to act more aggressively on the substrate materials than the alkali materials alone [8, 15]. Merkel et al. found the presence of large amounts of iron oxide tends to promote greater reaction of the ash with the cordierite filter material as well [16].

Failures of DPFs are most often attributed to a one time, catastrophic event, such as an uncontrolled DPF regeneration, or a single upstream engine component failure [19]. As DPFs have now been in commercial use for several years, field observations suggest that non-event-linked DPF failures also occur. Herein, the authors aim to (1) classify four modes of DPF failure observed during commercial fleet use and (2) seek to characterize the ash and cordierite substrate physical-chemical properties associated with non-event-linked DPF failure. Due to the complexity in fuel, lubricating oil, and engine operating conditions, consistent mechanisms for showing a slow degrade of DPF substrates are difficult to ascertain. To date, there is limited evidence from operational DPF failures which correlate the mechanics and PM chemistry to mode of failure. However, research to date appears to concur that alkaline ash components may reduce DPF substrate durability via various pathways that are still under investigation. To investigate these issues, the authors analyzed ash chemistry in cordierite DPF substrates and simultaneously characterized DPF failure mode. Specifically, post-mortem analysis of cordierite diesel particulate filters was performed. Ash composition was appraised via acid treatment of exhausted DPF samples and subsequently analyzed for inorganic components via ICP-OES; the result was compared with the data from scanning electron microscopy-energy dispersive spectrometry (SEM-EDS). SEM was applied to characterize the micro-structures of the different modes of DPF failures, and the corresponding elemental distributions were measured by EDS. XPS-AES was utilized to determine the surface chemical composition and the atomic state of DPF substrate surface which experienced different modes of failure. The authors utilized XRD to determine the crystalline structure of DPF samples, which specifically aimed to detect vitrification as DPF cordierite substrate become more amorphous from melting failure. The authors utilized SEMEDS to determine ash morphology and chemical composition.

\section{Materials and Methods}

\subsection{DPF Ash and EGR Coolant Leak-Derived Ash Analysis}

\subsubsection{Diesel Particulate Filters}

The DPF substrates used herein were provided by Hunsicker Emission Services LLC. All substrates used are exhausted OEM DPFs from heavy-duty diesel-powered vehicles belonging to commercial fleets. The DPF substrate failures characterized as pinhole failure, melt failure, and crack failure were observed in DPFs used in urban transit bus driving application. These substrate failures were irreversible. The DPF substrate failure characterized as fouling failure was observed in a DPF used in highway driving application. The vehicle had operated with an unnoticed exhaust gas recirculation (EGR) coolant leak for an extended period of time. The ash was sufficiently cleaned from this DPF substrate to allow the DPF to be re-installed on the vehicle for additional use.

Typical soot loadings and typical ash loadings in the exhausted urban transit bus DPFs were measured postmortem at 4-5 g soot/L substrate and 25-30 g ash/L substrate, respectively. These are moderately high soot and ash loadings for a DPF, but within the DPF substrate design parameters [13, 20]. Volumetric parameters of the DPFs are depicted in Table 1, and a cross-section photograph of an exhausted urban transit bus DPF is shown in Fig. 1. This figure demonstrates that the dark-colored DPF soot appears to be deposited on the inlet of the DPF. 
Table 1 Exhausted DPF characteristics from an urban transit bus fleet vehicle

\begin{aligned} & \hline \multicolumn{2}{l}{ Data } \\ & \hline Substrate composition Cordierite, EX-60 \\ & Length (cm) 30.5 \\ & Diameter (cm) 30.5 \\ & DPF volume (L) 22.2 \\ & Cell density (cpsi) 200 \\ & DPF weight, as received (kg) 18.5 \\ & Weight loss, combustibles (soot) $(\mathrm{g}$ soot/L substrate) 4.5 \\ & Weight loss, non-combustibles (ash) $(\mathrm{g}$ ash/L substrate) 26.6 \\ & \hline\end{aligned}

\subsubsection{ICP Analysis of DPF Ash and EGR Coolant Leak-Derived Ash}

The inlet half and the outlet half of an exhausted urban bus transit fleet DPF were crushed separately and stored separately prior to chemical analysis. Figure $2 d$ shows a DPF with the inlet plugged by EGR coolant leak-derived ash. Exhaust gas recirculation (EGR) cooler failure can cause coolant to leak into the exhaust after treatment system [21]. The chemical components of ash are determined experimentally via strong acid treatment to dissolve ash components. The specific procedure includes the following: the inlet half and outlet half of an entire DPF substrate were cut apart, crushed into powder, and stored separately. Next, $1.0 \mathrm{~g}$ of crushed inlet or outlet powder was dissolved separately into $0.1 \mathrm{~L}$ aqua regia solution with molar concentrations of 1.0 and 4.0 for hydrochloric acid and nitric acid, respectively. Reactions were carried out for 1 week on a magnetic stir plate with a stirring speed of $100 \mathrm{rpm}$. The solution was filtered to remove the insoluble components, which include cordierite. The leachate was then diluted by deionized water and analyzed for calcium, iron, zinc, sodium, potassium, sulfur, and phosphorus using ICPOES (PerkinElmer Optima 2100DV, US). A control test was

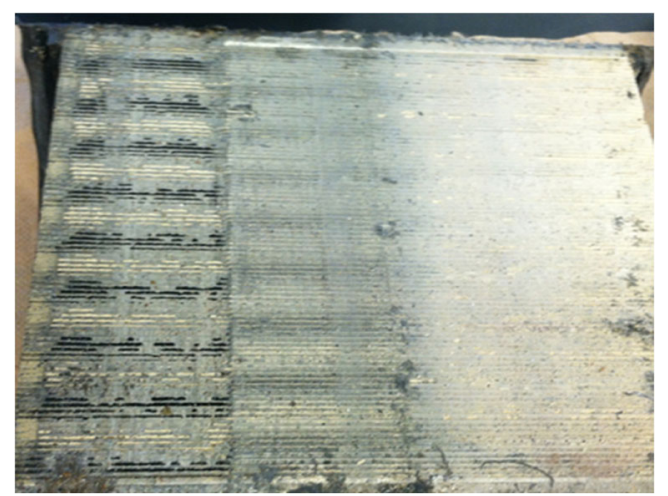

Fig. 1 Cross section of a DPF, showing inlet (left side) and outlet (right side) performed on unused cordierite substrate and EGR coolant leak-derived ash, using the same procedure.

\subsubsection{SEM-EDS Analysis of DPF Ash and EGR Coolant Leak-Derived Ash Particles}

DPF ash from an exhausted urban bus transit fleet DPF was collected from DPF inlet channel surfaces. The agglomeration of small ash particles form larger sized particles that are 45$160 \mathrm{~nm}$ [3]. Micro-structures and elemental maps of ash particles were determined by scanning electron microscopy energy dispersive spectrometer (SEM-EDS).

Exhaust gas recirculation (EGR) coolant failures or coolant leaks form unique ash particles in the exhaust which agglomerate on the DPF inlet face. The larger agglomerated EGR coolant leak-derived ash is different from lubricating oilderived ash in both morphology and chemical compositions due to the difference in formation pathway. The EGR coolant leak-derived ash was collected from the surface of the DPF substrate inlet face. Scanning electron microscopy energy dispersive spectrometer (SEM-EDS) (HITACHI, TM-1000) was applied to determine the physicochemical characteristics of EGR coolant leak-derived ash.

\subsection{Pinhole, Melt, and Crack Failure Analysis}

The elemental composition of DPF pinholes, melts, and cracks were compared with new, unused DPF samples. For each DPF failure, three parallel experiments were carried out on three different samples or area on those pinholes, melts, and cracks; each sample was analyzed with SEM-EDS, XRD, and XPS. XPS and SEM-EDS samples were removed from DPF samples of interest (melt, crack, pinhole areas) via tweezers. Samples were then rinsed with deionized water and dried in a $110{ }^{\circ} \mathrm{C}$ oven for $24 \mathrm{~h}$, prior to analysis.

The SEM-EDS analysis was carried out to characterize the micro-structures of new DPF, pinholes, cracked areas, and melted areas to reveal the physicochemical changes. The EDS signal was obtained from the depth of $2-10 \mu \mathrm{m}$ according to the accelerating voltage. XPS signal was obtained from the depth around $3 \mathrm{~nm}$.

Samples for XRD analysis were prepared by crushing melted, cracked, or pinholed areas into a fine powder with a mortar and pestle. The crushed sample was rinsed with deionized water and dried in a $110^{\circ} \mathrm{C}$ oven for $24 \mathrm{~h}$, prior to analysis. X-ray diffraction (XRD) was applied to characterize the physicochemical properties of cordierite by determining crystalline phase change before and after DPF melting and vitrification. The X-ray diffraction (XRD) (MiniFlex, Rigaku) analyses were carried out under electric voltage/current of $30 \mathrm{kV} /$ $15 \mathrm{~mA}$. The scanning angle ranges from $10^{\circ}$ to $90^{\circ}$ with continuous scanning and the scanning step was $0.02^{\circ}$. 
Fig. 2 Photographs of a DPF which experiences (a) pinholes, (b) melts, (c) cracks, and (d) EGR failure
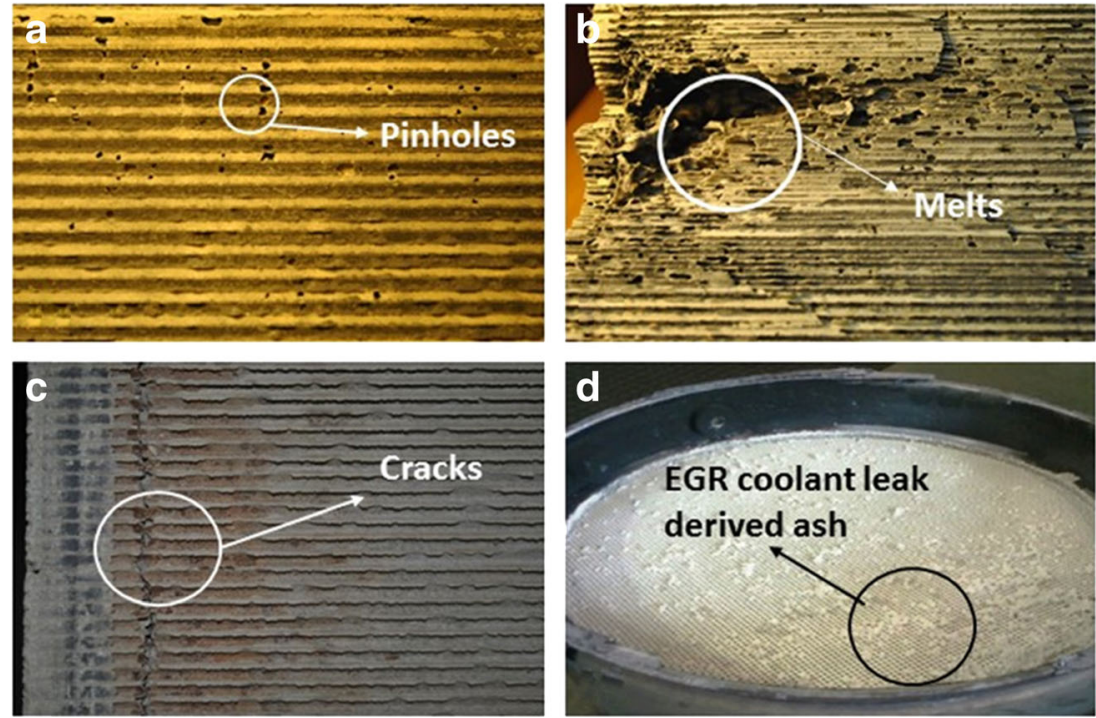

DPF samples were analyzed by X-ray photoelectron and Auger electron spectroscopies (XPS-AES). The XPS-AES analysis was carried out with PHI Veraprobe 5000 XPS equipped with monochromated $\mathrm{AlK}$ alpha source. The signal was obtained from the top $10 \mathrm{~nm}$ of the sample with an analysis area of $100 \mu \mathrm{m} \times 1400 \mu \mathrm{m}$. The composition and chemical state were investigated on the basis of areas and binding energies of Ca 2p, Mg 2s, Al 2p, Si 2p, C 1s, O 1s, Zn 2p, Na $1 \mathrm{~s}$, and Fe $2 \mathrm{p}$ photoelectron peaks. The XPS-AES could provide intrinsic information of the surface chemical composition and their valences via electron detection with kinetic energies between 10 and $2000 \mathrm{eV}$.

\section{Results and Discussion}

\subsection{Classification of Failures}

Four specific modes of failure were observed for compromised DPFs provided by Hunsicker Emissions Services LLC. Figure 2 illustrates the mode of failure for four separate DPFs. The authors have characterized the failure mechanisms based on the visual appearance by which the DPF failed. Specifically, the figure demonstrates failure by pinholes (a), melting (b), cracking (c), and EGR coolant leak-derived ash (d). Pinholes were failures observed when DPFs were cut in half and 0.1-10-mm holes between channels were observed by the authors. Melting failures were observed for DPFs where a significant volume of the DPF melted and left a void. Cracking failures were observed on cross sections of DPFs, where a crack continued through the entire cross section of a DPF. The crack was located within 1 in. of the DPF outlet face, but its presence was not observable prior to cutting the DPF and exposing the cross section. The crack pattern is most likely attributed to the difference of the thermal expansions among these crystalline phases [8, 15, 16, 22]. Fouling failures were DPFs with layers of agglomerated ash on the inlet face that the DPF no longer was permeable via exhaust. These samples were sacrificially utilized for ash chemical appraisal, XRD analysis, XPS analysis, and SEM characterization, which are detailed herein.

\subsection{Crushed DPF Substrate Ash and EGR Coolant Leak-Derived Ash Chemical Compositions}

DPF ash composition varies between vehicles, but it can be generally stated that ash samples from light-duty and heavyduty vehicles will contain oxides of calcium, zinc, magnesium, sulfur, and phosphorus from lubricating oil, and a lesser amount of metal oxides from engine wear $[14,16]$. In the
Table 2 DPF inlet and outlet ash chemical compositions

\begin{tabular}{|c|c|c|c|c|c|c|c|c|}
\hline \multirow[t]{2}{*}{ Component } & \multicolumn{8}{|c|}{ mg component/g DPF substrate } \\
\hline & $\mathrm{Ca}$ & $\mathrm{Zn}$ & $\mathrm{Fe}$ & $\mathrm{Na}$ & $\mathrm{K}$ & $\mathrm{S}$ & $\mathrm{P}$ & Total \\
\hline Average inlet ash & 5.20 & 3.10 & 2.71 & 1.25 & 0.15 & 4.60 & 3.05 & 20.06 \\
\hline Average outlet ash & 2.60 & 1.40 & 2.23 & 1.45 & 0.01 & 2.20 & 1.45 & 11.34 \\
\hline Unused DPF & 0.002 & 0 & 0.645 & 0.001 & 0 & 0.134 & 0.349 & 1.131 \\
\hline
\end{tabular}




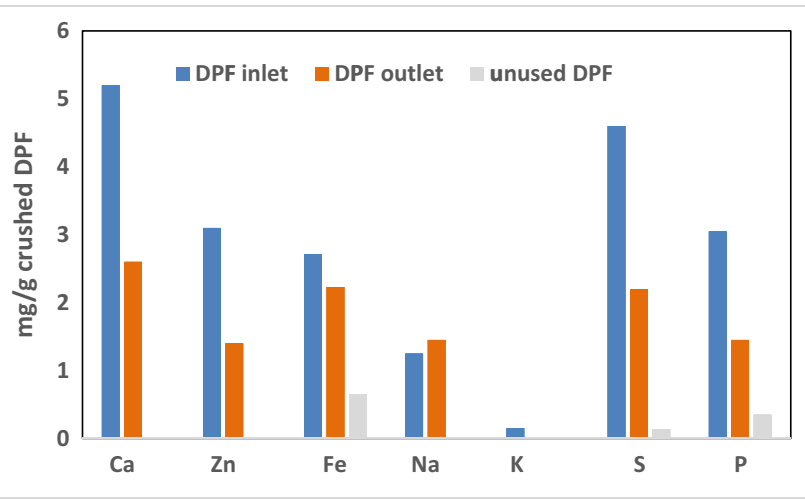

Fig. 3 Commercial fleet DPF ash chemical components (mg ash components/g of DPF substrate)

present study, ash chemical compositions are appraised by either ICP-OES or SEM-EDS. The authors focused on seven components, specifically, $\mathrm{Ca}, \mathrm{Zn}, \mathrm{Fe}, \mathrm{Na}, \mathrm{K}, \mathrm{S}$, and P. Results of ash composition analysis of a crushed DPF substrate based on ICP-OES are depicted in Table 2 and Fig. 3. Corresponding SEM-EDS photograph and spectra are shown in Fig. 4.

The total ash loading found in the separately crushed inlet and outlet substrate halves of an urban transit fleet DPF was consistent with ash deposition results reported by others [13, 14]. Figure 3 plots the inlet and outlet concentration by chemical species. Considering the chemical composition distributions in Fig. 3, Ca composed the majority of ash with a concentration of 5.2 and $2.6 \mathrm{mg} / \mathrm{g}$ for the inlet and the outlet. Other compounds $\mathrm{S}, \mathrm{P}, \mathrm{Na}, \mathrm{Zn}$, and $\mathrm{Fe}$ are found in the range of 1.25 to $4.6 \mathrm{mg} / \mathrm{g}$. Potassium was found as trace levels in both the inlet and outlet, with concentrations of $0.15 \mathrm{mg} / \mathrm{g}$ for the inlet and $0.01 \mathrm{mg} / \mathrm{g}$ for the outlet.

These results are in consensus with observations made by others, which show primary ash constituents including $\mathrm{CaO}$
(21-30 wt.\%), sulfate (10-39 wt.\%), $\mathrm{MgO}$ (5-7 wt.\%), phosphate (11-16 wt.\%), and $\mathrm{ZnO}(10-14$ wt.\%), with $\mathrm{Na}$ and $\mathrm{K}$ observed trace levels $(<1 \mathrm{wt} . \%)$, and varying levels of $\mathrm{Fe}_{2} \mathrm{O}_{3}$ $(<1$ to $25 \%$ ) dependent on engine and exhaust system corrosion $[16,23]$.

The detection of sodium and iron at relatively high concentrations in the crushed substrate of the exhausted DPF, as shown in Table 2, lends possible support to the laboratory controlled studies that observed corrosive interaction of sodium with substrate materials, and the role of iron in increasing the aggressiveness of this interaction. ICP results of new, unused cordierite samples are provided in Table 2 and Fig. 3 for reference. Table 3 compares the ash composition found in the crushed DPF with the EGR coolant leak failure ash composition. These two ash types have similar chemical compositions, with high concentration of $\mathrm{Ca}, \mathrm{Zn}, \mathrm{Na}, \mathrm{S}$, and P. The EGR coolant leak failure ash is slightly lower in the iron concentration than found in the crushed DPF samples, and higher in potassium.

\subsection{Characterizations of Pinholes, Melting, Cracking Sections, and EGR Failure Ash}

\subsubsection{Characterizing an Unused DPF Substrate}

Figure 5 depicts the XRD analysis profile of a new, unused DPF substrate without pinholes, melting, or cracks. The XRD analysis was performed with scanning angle ranges from $\theta=10^{\circ}$ to $\theta=90^{\circ}$ under a wavelength of $1.5406 \AA$. XRD analysis indicates that the unused DPF substrate possessed two crystalline structures. These two crystalline phases, which include $\mathrm{Mg}_{2} \mathrm{Al}_{4} \mathrm{Si}_{5} \mathrm{O}_{18}$ (a) and minor phase of $(\mathrm{Mg}$, $\mathrm{Fe})_{2} \mathrm{Al}_{4} \mathrm{Si}_{5} \mathrm{O}_{18}$, show a strong correlation with the $\mathrm{XRD}$ peaks,
Fig. 4 SEM-EDS spectra of DPF ash particles (coated by $\mathrm{Au} / \mathrm{Pd}$ )

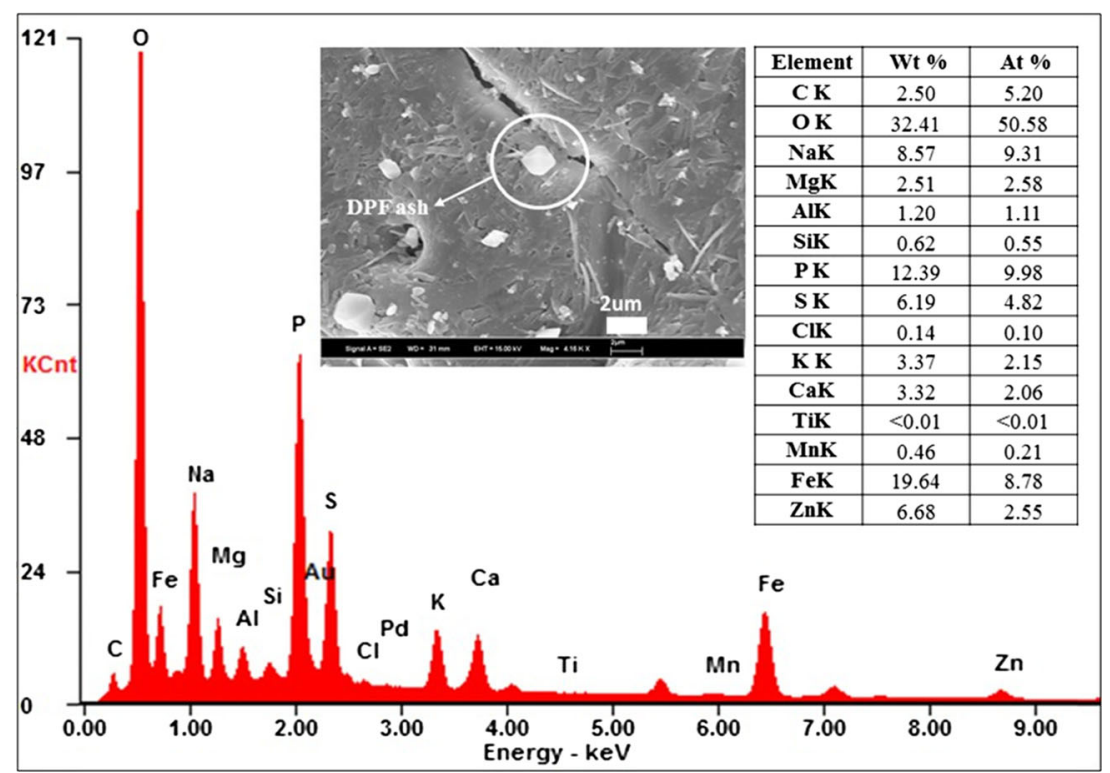


Table 3 Comparison of chemical compositions between DPF ash and EGR coolant leak ash

\begin{tabular}{lllllllll}
\hline Component & \multicolumn{1}{l}{ Percentage } & & & & & \\
\cline { 2 - 8 } & $\mathrm{Ca}$ & $\mathrm{Zn}$ & $\mathrm{Fe}$ & $\mathrm{Na}$ & $\mathrm{K}$ & $\mathrm{S}$ & $\mathrm{P}$ & Total \\
\hline Average inlet ash & 27.46 & 16.38 & 10.91 & 6.60 & 0.792 & 23.59 & 14.27 & 100 \\
Average outlet ash & 25.45 & 13.71 & 15.53 & 14.19 & 0.097 & 20.24 & 10.78 & 100 \\
EGR & 22.94 & 21.23 & 3.870 & 11.87 & 2.27 & 24.84 & 12.98 & 100 \\
\hline
\end{tabular}

as they form the major chemical composition of cordierite. The average crystallinity of both phases, for the unused DPF, based on calculating the crystal area, is $97 \%$ for $\mathrm{Mg}_{2} \mathrm{Al}_{4} \mathrm{Si}_{5} \mathrm{O}_{18}$ (a) and $99 \%$ for $(\mathrm{Mg}, \mathrm{Fe})_{2} \mathrm{Al}_{4} \mathrm{Si}_{5} \mathrm{O}_{18}$-indicating a high degree of crystallinity for the unused DPF.

SEM photographs in Fig. 6 compare the microstructures of unused DPF with pinholes, melts, and cracks. The SEM photograph of the unused DPF shows a regular shape with a layered structure. This structure changes as the layers melt and combine together in pinholes, melts, and cracks. The corresponding EDS spectra are illustrated in Fig. 8 and compared in Table 4. The EDS spectra in Fig. 8a show $\mathrm{Ca}, \mathrm{Zn}, \mathrm{K}$, and $\mathrm{Fe}$ are not present in the new, unused DPF samples.

The XPS analysis in Fig. 7 compares XPS spectra of the unused DPF substrate with pinhole, melt, and cracks. A comparison of the results is also provided in Table 5. The XPS spectra in Fig. 7a show the new, unused DPF substrate is free of $\mathrm{Ca}, \mathrm{Zn}, \mathrm{K}, \mathrm{Na}$, and $\mathrm{Fe}$.

\subsubsection{Characterizing Failure by Pinholes}

The XRD analysis of pinhole areas in Fig. 5 shows two unique crystalline phases, the major crystalline phase $\mathrm{Zn}_{2} \mathrm{Al}_{4} \mathrm{Si}_{5} \mathrm{O}_{18}$ (d) and the minor crystalline phases of $\mathrm{MgAl}_{2} \mathrm{O}_{4}$ (e). These two phases are not found in the XRD pattern of the new, unused DPF sample and may indicate possible chemical reaction between the cordierite substrate and ash. The crystallinity of (d) $\mathrm{Zn}_{2} \mathrm{Al}_{4} \mathrm{Si}_{5} \mathrm{O}_{18}$ and (e) $\mathrm{MgAl}_{2} \mathrm{O}_{4}$ is 99 and $89 \%$, respectively. This suggests the pinhole samples display less perfect crystal orientation and more amorphous phases.

The XPS spectrum of the pinhole areas is provided in Fig. 7b. This spectrum shows the presence of $\mathrm{Na}, \mathrm{Fe}$, and $\mathrm{Ca}$ at the surface of the pinhole area. The relative amounts of the ash components found are $0.53 \% \mathrm{Na} 1 \mathrm{~s}, 1.85 \% \mathrm{Ca}$ $2 \mathrm{p}$, and $0.17 \%$ Fe $2 \mathrm{p}$.

The SEM-EDS spectra of the pinhole areas are located in Fig. 8b. This spectra show the presence of major levels of $\mathrm{Na}$, $\mathrm{Fe}, \mathrm{Ca}, \mathrm{P}$, and $\mathrm{Zn}$. The presence of high levels of zinc in the
Fig. 5 XRD patterns from unused DPF, pinholes, melts, and crack samples

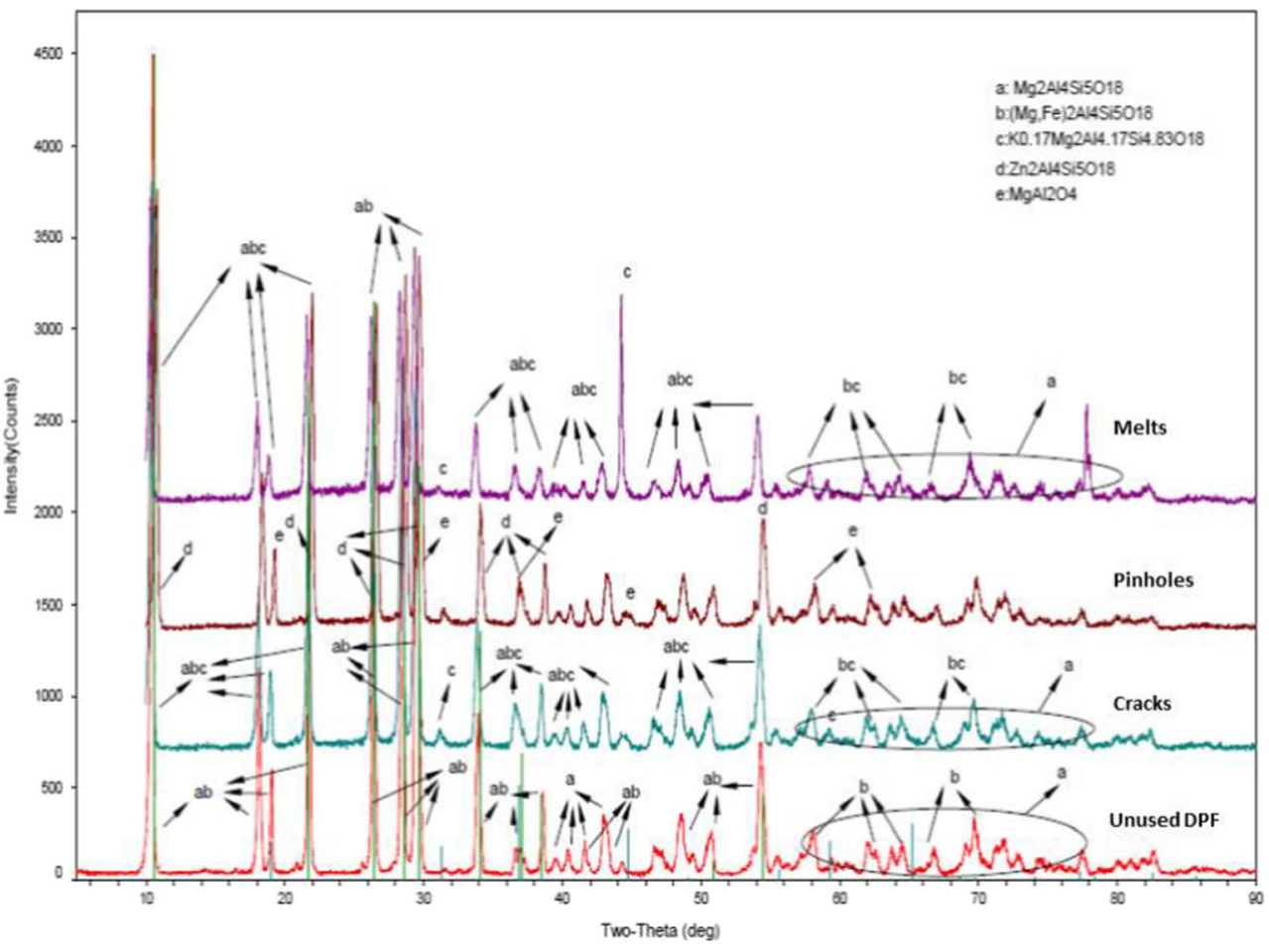


Fig. 6 SEM photographs of a unused cordierite, $\mathbf{b}$ pinholes, $\mathbf{c}$ melts, and $\mathbf{d}$ cracks
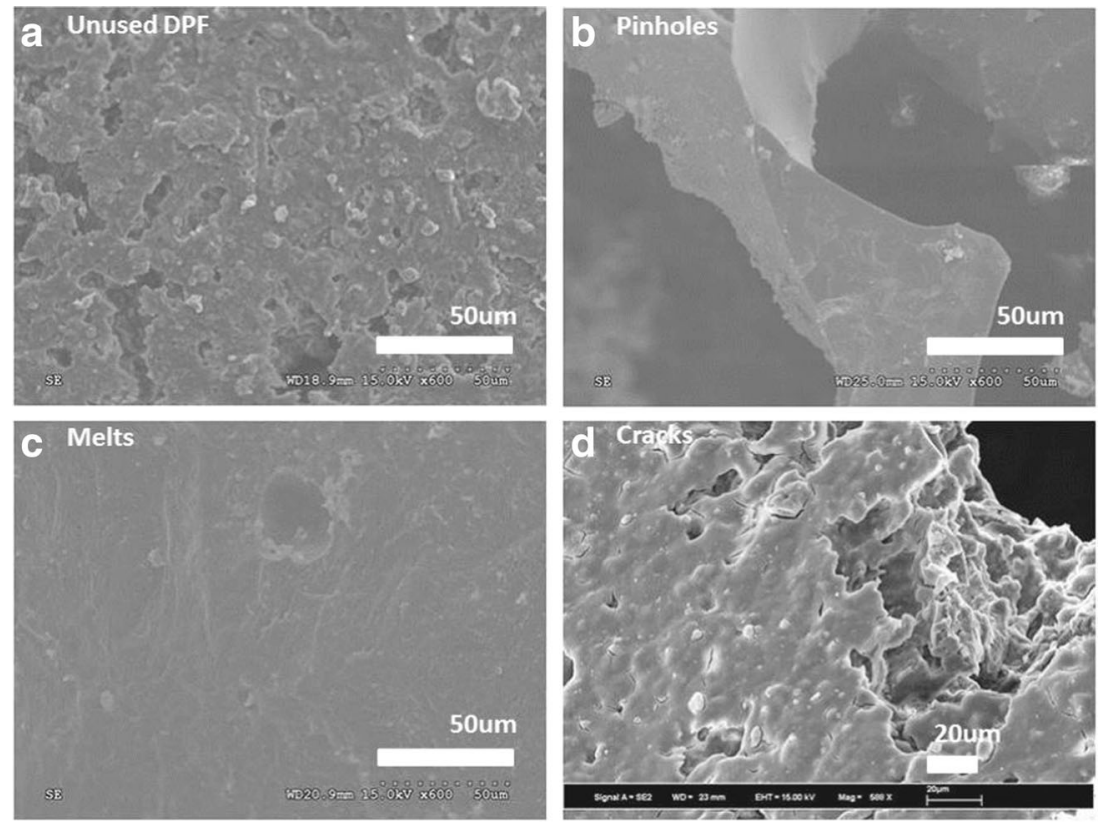

XRD data and SEM-EDS data, but not the XPS data, suggests zinc might penetrate deeper into the substrate, below the top 10-nm surface layer measured by XPS.

\subsubsection{Characterizing Failure by Melting}

The XRD spectra of DPF melts in Fig. 5 show three unique crystalline phases, two with major crystalline phases of $\mathrm{Mg}_{2} \mathrm{Al}_{4} \mathrm{Si}_{5} \mathrm{O}_{18}$ (a) and $(\mathrm{Mg}, \mathrm{Fe})_{2} \mathrm{Al}_{4} \mathrm{Si}_{5} \mathrm{O}_{18}$ (b), and one minor crystalline phase of $\mathrm{K}_{0.17} \mathrm{Mg}_{2} \mathrm{Al}_{4.17} \mathrm{Si}_{4.83} \mathrm{O}_{18}$ (c). The crystallinity of $\mathrm{Mg}_{2} \mathrm{Al}_{4} \mathrm{Si}_{5} \mathrm{O}_{18}$ (a), $(\mathrm{Mg}, \mathrm{Fe})_{2} \mathrm{Al}_{4} \mathrm{Si}_{5} \mathrm{O}_{18}$ (b), and

Table 4 Chemical distribution according to SEM-EDS spectra

\begin{tabular}{rrrrr}
\hline \multicolumn{5}{c}{ Concentration wt $\%$} \\
\cline { 2 - 5 } & New DPF & Pinhole failure & Melting failure & Cracking failure \\
\hline O K & 35.69 & 16.23 & 28.37 & 28.13 \\
$\mathrm{C} \mathrm{K}$ & 1.92 & 23.29 & 7.09 & 7.25 \\
$\mathrm{Mg} \mathrm{K}$ & 9.03 & 6.74 & 10.37 & 8.75 \\
$\mathrm{Si} \mathrm{K}$ & 28.97 & 16.12 & 27.54 & 22.64 \\
$\mathrm{Al} \mathrm{K}$ & 21.97 & 15.91 & 20.13 & 19.25 \\
$\mathrm{Na} \mathrm{K}$ & 0.02 & 1.43 & 0.17 & 1.04 \\
$\mathrm{P} \mathrm{K}$ & & 1.61 & 0.68 & 1.7 \\
$\mathrm{~S} \mathrm{~K}$ & & $<0.01$ & $<0.01$ & \\
$\mathrm{~K} \mathrm{~K}$ & & $<0.01$ & $<0.01$ & 0.48 \\
$\mathrm{Ca} \mathrm{K}$ & & 1.13 & 0.91 & 2.2 \\
$\mathrm{Fe} \mathrm{K}$ & & 4.24 & 3.09 & 2.07 \\
$\mathrm{Zn} \mathrm{K}$ & & 13.31 & & 6.49 \\
$\mathrm{Nb} \mathrm{L}$ & 1.92 & & & \\
Ti K & 0.48 & & & \\
\hline
\end{tabular}

$\mathrm{K}_{0.17} \mathrm{Mg}_{2} \mathrm{Al}_{4.17} \mathrm{Si}_{4.83} \mathrm{O}_{18}$ (c) is 77,82 , and $85 \%$, respectively. The crystallinity of the $\mathrm{Mg}_{2} \mathrm{Al}_{4} \mathrm{Si}_{5} \mathrm{O}_{18}$ (a) and $(\mathrm{Mg}$, $\mathrm{Fe})_{2} \mathrm{Al}_{4} \mathrm{Si}_{5} \mathrm{O}_{18}$ (b) phases in the melted areas is significantly less than the crystallinity calculated for these phases in the unused DPF, indicating that these two phases are less crystalline due to a shift into a more amorphous, or glass-like structure. This result demonstrates that DPF melting failure observed in the field can be confirmed via XRD.

The corresponding XPS spectrum of the melted DPF in Fig. 7c shows the melted surface contains peaks of $\mathrm{Na}$ and Ca. The SEM-EDS spectra of melts are shown in Fig. 8c. The melt spectra show the presence of major levels of Fe, Ca, P, and minor levels of $\mathrm{Na}$.

\subsubsection{Characterizing Failure by Cracking}

The XRD analysis in Fig. 5 of the cracked DPF sample identifies the same phases as the melted sample. This includes $\mathrm{Mg}_{2} \mathrm{Al}_{4} \mathrm{Si}_{5} \mathrm{O}_{18}$ (a), ( $\left.\mathrm{Mg}, \mathrm{Fe}\right)_{2} \mathrm{Al}_{4} \mathrm{Si}_{5} \mathrm{O}_{18}$ (b), and $\mathrm{K}_{0.17} \mathrm{Mg}_{2} \mathrm{Al}_{4.17} \mathrm{Si}_{4.83} \mathrm{O}_{18}$ (c). The respective crystallinity for the two major phases is $91 \%$ for $\mathrm{Mg}_{2} \mathrm{Al}_{4} \mathrm{Si}_{5} \mathrm{O}_{18}$ (a) and $93 \%$ for $(\mathrm{Mg}, \mathrm{Fe})_{2} \mathrm{Al}_{4} \mathrm{Si}_{5} \mathrm{O}_{18}$ (b). The crystallinity of the minor phase $\mathrm{K}_{0.17} \mathrm{Mg}_{2} \mathrm{Al}_{4.17} \mathrm{Si}_{4.83} \mathrm{O}_{18}$ (c) is $88 \%$.

The XPS spectrum of the cracked DPF substrate is located in Fig. 7d. The spectrum shows the presence of calcium and zinc. The SEM-EDS spectra of cracked substrate are located in Fig. 7d. This spectrum shows the presence of major levels of $\mathrm{Ca}$ and $\mathrm{Zn}$, as well as $\mathrm{P}, \mathrm{Na}, \mathrm{K}$, and Fe. The presence of $\mathrm{Zn}$ near cracks in the substrate is consistent with the findings of Maier et al. [8], although the underlying mechanisms are not yet understood as to why zinc concentrations are prevalent near cracks. 

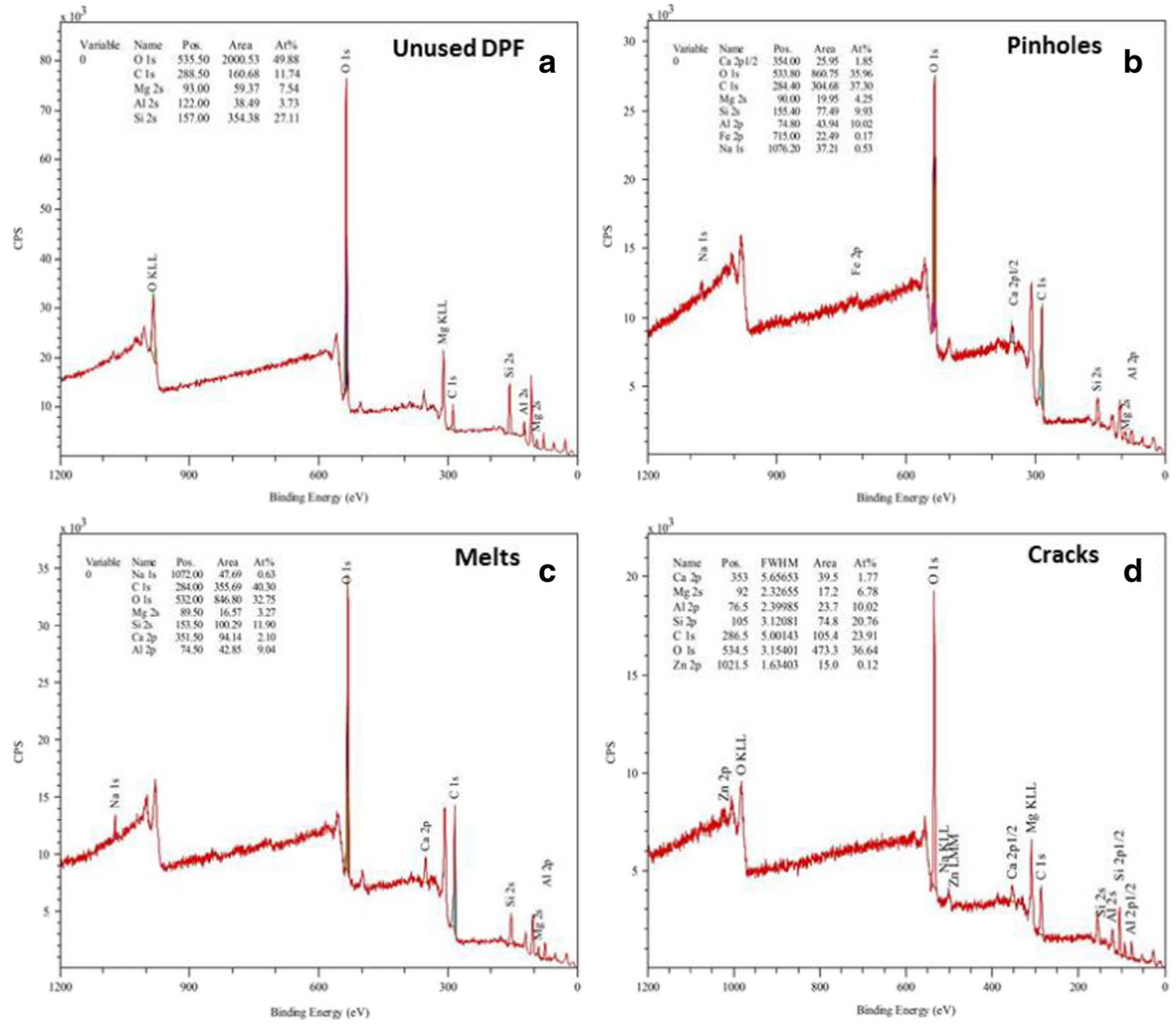

Fig. 7 XPS scanning survey spectra of a unused DPF, $\mathbf{b}$ pinholes, $\mathbf{c}$ melts, and $\mathbf{d}$ cracks

\subsubsection{Fouling from EGR Coolant Leak-Derived Ash Particles}

Various pathways are possible for engine fluids to come in contact with the DPF substrate. Coolant leaks from high temperature exhaust gas recirculation (EGR) failure [21], excess lubricant from engine failure, and fuel from incomplete combustion all possess the capability to enter the exhaust stream and to contaminate the DPF. The white ash substance shown layered on the DPF inlet face are clusters of ash as large as 3$7 \mathrm{~mm}$ in diameter. The ash clusters formed when the vehicle was driven with an unnoticed EGR coolant leak failure for an extended period of time. As coolant passes through the engine's combustion chamber, the increased percent moisture in the exhaust produces steam. The ash agglomerates formed in these conditions are larger, and different in morphology, from typical engine lube-derived ash, causing them to load differently in the DPF channels. The larger ash agglomerates can also bridge more easily across the DPF inlet face channels than typical DPF ash, creating a layer of ash/soot on the DPF face. This can result in relatively high engine back pressure at relatively low DPF ash loadings, increasing the frequency required for DPF maintenance.

Scanning electron microscopy (HITACHI, TM1000) of the EGR coolant-derived ash particles, illustrated in Fig. 9, shows the white ash substance on the DPF inlet face is comprised of 5-10- $\mu \mathrm{m}$-sized ash agglomerates. The agglomerates are loosely packed and can act as an adsorbent for smaller soot or ash particles in the exhaust gas. An elemental spectrum of the white ash substance which was acquired using EDS under accelerating voltage of $15 \mathrm{kV}$ shows the observed EGR coolant leak derived ash is composed of similar chemical compounds as typical DPF lube ash, although at different elemental distributions. The EDS results show no detected zinc or magnesium and much higher levels of potassium and sodium. High levels of potassium are indicative of a coolant leak, as fully formulated HDD coolants may contain significant quantities of S (sulfur), $\mathrm{P}$ (phosphorus), $\mathrm{Na}$ (sodium), and $\mathrm{K}$ (potassium) [21].

While analyzing the chemical composition of EGR failure ash, the authors observed shinny spots on the 

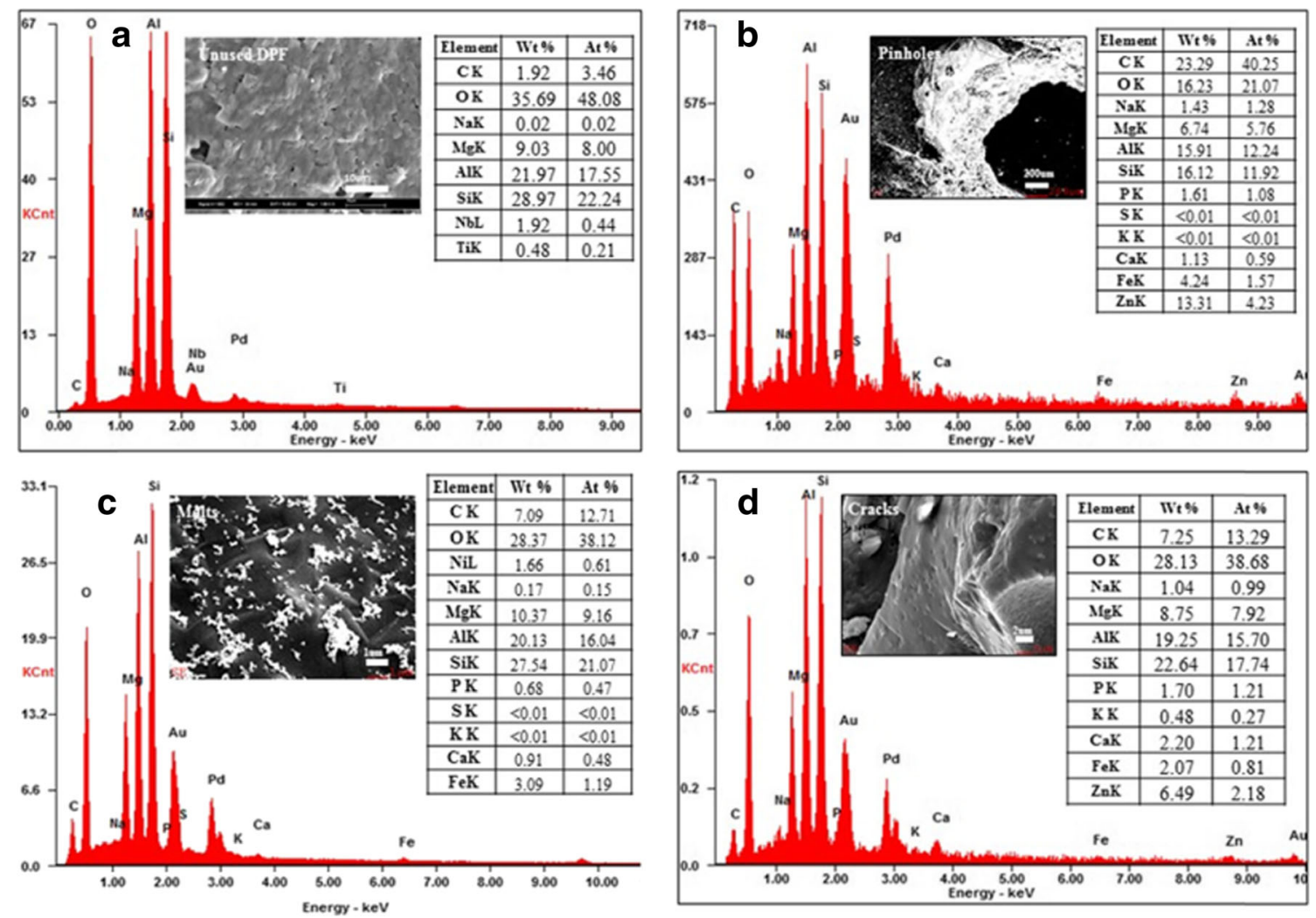

Fig. 8 SEM-EDS photographs and spectra of a unused DPF, b pinholes, $\mathbf{c}$ melts, and $\mathbf{d}$ cracks (material coated with $\mathrm{Au} / \mathrm{Pd}$ )

particle surface (Fig. 10). EDS analysis confirms that $48.9 \%$ of weight of these white ash particles are iron. Merkel indicated the iron in DPF ash is mainly attributed to rusting of exhaust component upstream [16]. Therefore, the EGR coolant failure could contribute to exhaust system corrosion and transport iron particles within the DPF.

The presence of high levels of alkalis $(\mathrm{Na}, \mathrm{K})$ in the EGR coolant leak-derived ash can compromise the durability of the DPF twofold. The alkalis have been observed to poison the catalyst coatings in the diesel oxidation catalysts and diesel particulate filters with respect to NO oxidation, or $\mathrm{NO}_{2}$ make [21]. The reduction of the $\mathrm{NO}$ oxidation performance of the DOC and DPF can compromise the soot regeneration process in the DPF during normal vehicle operating conditions, resulting in higher soot loads in the DPF. When the soot does light off, the increased exotherm from the higher soot loads can generate excessive temperatures in the DPF, leading to the severe operating conditions at which the alkalis and iron have been observed to interact with cordierite and silicon carbide substrate materials, resulting in a pinhole, melt, and crack [16]. This emphasizes the importance of regular cooling system maintenance by the vehicle operator to protect the particulate matter emission capture efficiency and useful life of the DPF.

\section{Summary/Conclusions}

The results presented herein characterized observed failures of cordierite DPFs during commercial fleet use. The characterization incorporated a number of techniques, including bulk and surface characterization analysis. The observed failures were classified as pinhole failure, melt failure, crack failure, and fouling failure. The detailed analysis of ash composition from a crushed DPF substrate confirmed the varying levels of

Table 5 Surface elemental partition according to XPS scanning spectra Concentration at. $\%$

New DPF Pinhole failure Melting failure Cracking failure

\begin{tabular}{rrccc}
$\mathrm{O} 1 \mathrm{~s}$ & 31.05 & 35.96 & 32.75 & 36.64 \\
$\mathrm{C} 1 \mathrm{~s}$ & 41.16 & 37.3 & 40.3 & 23.91 \\
$\mathrm{Mg} 2 \mathrm{~s}$ & 6.76 & 4.25 & 3.27 & 6.78 \\
$\mathrm{Si} 2 \mathrm{p}$ & 13.09 & 9.93 & 11.9 & 20.76 \\
$\mathrm{Al} 2 \mathrm{p}$ & 7.94 & 10.02 & 9.04 & 10.02 \\
$\mathrm{Fe} 2 \mathrm{p}$ & - & 0.17 & - & - \\
$\mathrm{Na} 1 \mathrm{~s}$ & - & 0.53 & 0.63 & - \\
$\mathrm{Zn} 2 \mathrm{p}$ & - & - & - & 0.12 \\
$\mathrm{Ca} 2 \mathrm{p} 1 / 2$ & - & 1.85 & - & - \\
$\mathrm{Ca} 2 \mathrm{p}$ & - & - & 2.1 & 1.77 \\
\hline
\end{tabular}


Fig. 9 SEM images at $15.0 \mathrm{kV}$, showing surface structures of EGR coolant leak-derived ash articulate under different magnifications ranging from $\mathbf{a}-\mathbf{d}$ 500 to $10 \mathrm{~K}$

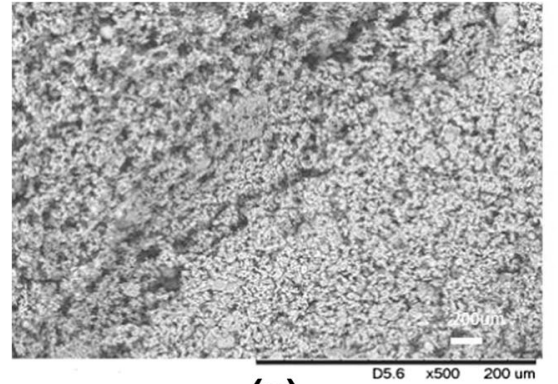

(a)

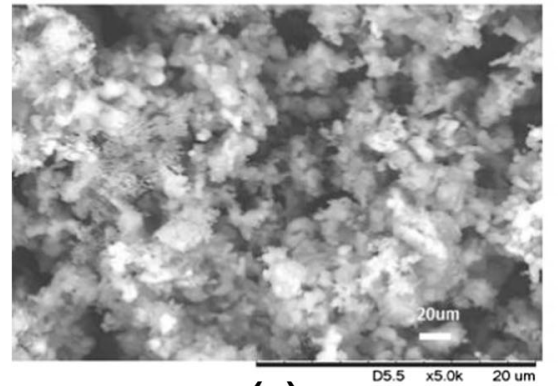

(c)

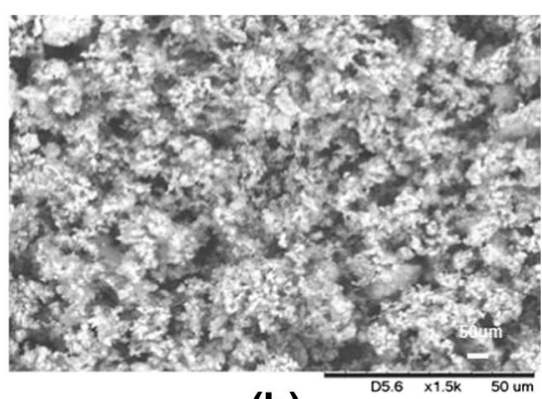

(b)

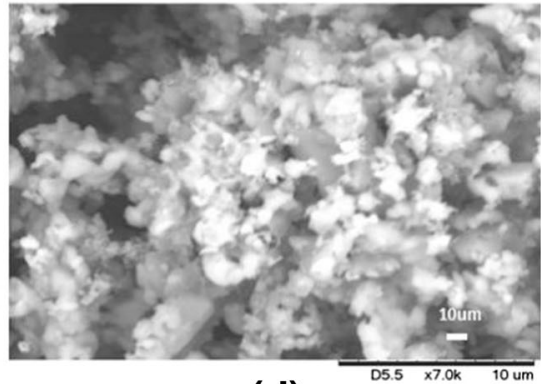

(d)
$\mathrm{Ca}, \mathrm{Fe}, \mathrm{S}, \mathrm{P}, \mathrm{Na}, \mathrm{K}$, and $\mathrm{Zn}$ as ash species. XRD analysis on cordierite substrate indicates significant crystalline phase changes following pinhole failure and melt failure. Specifically, the crystallinity of cordierite substrate phases decreased from 97 to $99 \%$ for the new DPF to only 77,82 , and $85 \%$ for melt failure samples. Further, SEM-EDS identified iron at elevated levels within pinhole, melted, and cracked areas, in the presence of additional ash materials and alkali metals. Additionally, XPS surface analysis identified $\mathrm{Na}$ - and $\mathrm{Fe}$-rich ash near pinhole and melt areas and $\mathrm{Zn}$-rich ash near crack areas. EDS analysis determined chemical composition of EGR coolant leak-derived ash agglomerate is composed of sodium, phosphorus, sulfur, potassium, calcium, and iron, similar to the composition of typical DPF ash, but with higher than normal level of alkalis Na and K. The EGR coolant leak ash agglomerates are also larger than typical DPF ash agglomerates, different in morphology, and can shield the DPF's inlet

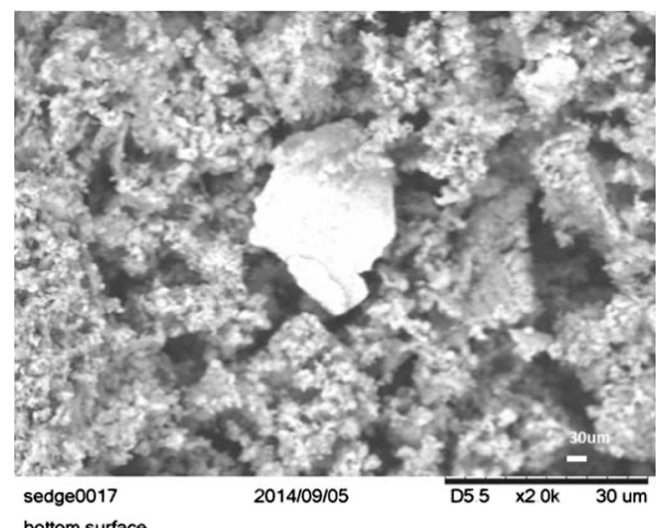

Fig. 10 SEM image showing an iron particle embedded within an EGR coolant leak-derived ash particulate face such that DPFs become impenetrable to exhaust, rendering vehicles temporarily un-operable. Field observations of failed commercial fleet DPF substrates show different modes of degradative failure including pinholes, melts, and cracks. Analysis reported herein of cordierite DPF failure during commercial fleet use offers support to previous laboratory controlled research findings that suggest ash components, more specifically high levels of iron and alkalis in the presence of additional ash materials, influence monolithic cordierite DPF substrate failure.

Acknowledgments This work is supported by Lehigh University and Hunsicker Emissions Services LLC through Research for Advanced Manufacturing in Pennsylvania Program (RAMP) Project and Pennsylvania Infrastructure Technology Alliance (PITA).

\section{References}

1. Transportation (2014). U.S.D.O.T, National Transportation Statistics: 48

2. USEPA: National Emissions Inventory (NEI) Air Pollutant Emissions Trends Data and Estimation Procedures. 1970-2013 Average annual emissions. (2013)

3. Liati, A., et al.: Metal particle emissions in the exhaust stream of diesel engines: an electron microscope study. Environ. Sci. Technol. 47(24), 14495-14501 (2013)

4. USEPA: Heavy Duty Engine and Vehicle Standards and Highway Diesel Fuel Sulfur Control Requirements. EPA420-F-00-057. (2000)

5. Fino: Diesel emission control: catalytic filters for particulate removal. Sci. Technol. Adv. Mater. 8, 93-100 (2007)

6. Maricq, M.M.: Chemical characterization of particulate emissions from diesel engines: a review. J. Aerosol Sci. 38(11), 1079-1118 (2007) 
7. Dario, M.T., A, B.: Interaction of some pollutant oxides on durability of silicon carbide as a material for diesel vehicle filters. J. Mater. Sci. 33, 139-145 (1998)

8. Maier, N., et al.: Mechanisms and orientation dependence of the corrosion of single crystal cordierite by model diesel particulate ashes. J. Eur. Ceram. Soc. 30(7), 1629-1640 (2010)

9. Hardenberg, H.O., Hase, F.W.: An empirical formula for computing the pressure rise delay of a fuel from its cetane number and from the relevant parameters of direct-injection diesel engines. SAE International. Paper \#: 790493. (1979)

10. Konstandopoulos, A., Johnson, J.H.: Wall-Flow Diesel Particulate Filters their Pressure Drop and Collection Efficiency. SAE International. Paper \#:890405. (1989)

11. Stamatelos, A.M.: A review of the effect of particulate traps on the efficiency of vehicle diesel engines. Energy Convers. Manag. 38(1), 83-89 (1997)

12. Stratakis, G.A., Psarianos, D.L., Stamatelos, A.M.: Experimental investigation of the pressure drop in porous ceramic diesel particulate filters. Proc. Inst. Mech. Eng. D 216(9), 773-784 (2002)

13. Aravelli, K.A., A, H.: Improved Lifetime Pressure Drop Management for Robust Cordierite (RC) Filters with Asymmetric Cell Technology (ACT). SAE International. Paper \#: 2007-010920. (2007)

14. Sappok, A., M, S., Vianna, T., Wong, V.: Characteristics and Effects of Ash Accumulation on Diesel Particulate Filter Performance: Rapidly Aged and Field Aged Results. SAE International.Paper \#:2009-01-1086. (2009)
15. Choi, B., B, L., Jeong, J.W.: Effects of hydrothermal aging on SiCDPF with metal oxide ash and alkali metals. J. Ind. Eng. Chem. 15, 707-715 (2009)

16. Merkel, G., W, C., Warren, C.: Thermal Durability of Wall-Flow Ceramic Diesel Particulate Filters. SAE International. Paper \#: 2001-01-0190. (2001)

17. Montanaro, L., A, B.: Influence of some pollutants on the durability of cordierite filters for diesel cars. Ceram. Int. 20(3), 169-174 (1994)

18. Zhang, B., Gong, J.-k., E, J.-q., Li, Y.: Failure recognition of the diesel particulate filter based on catastrophe theory. Can. J. Chem. Eng. 94, 596-602 (2016). doi:10.1002/cjce.22424

19. C.A.R.B: Evaluation of particulate matter filters in on road heavy duty diesel vehicle applications. (2015)

20. McCormick, W.A.: Impact of biodiesel impurities on the performance and durability of DOC, DPF and SCR technologies. SAE International. Paper \#:2011-01-1136. (2011)

21. Lopez De Jesus, Y.M., et al.: Effect of coolant exposure on diesel exhaust after treatment performance. SAE International. Paper \#:2012-01-1091. (2012)

22. O'Sullivan, D., et al.: Degradation resistance of silicon carbide diesel particulate filters to diesel fuel ash deposits. J. Mater. Res. 19(10), 2913-2921 (2004)

23. Givens, W.: Lube formulation effects on transfer of elements to exhaust after treatment system components. SAE International 2003-01-3109. (2003) 